\title{
PERT Simülasyon Yöntemiyle Denizyolu Lojistiği İhracat Süreç Analizi
}

\author{
Sibel BAYAR ${ }^{1}$ ve Ercan AKAN $^{2}$
}

Öz

Uluslararası ticaretin en yoğun olarak gerçekleştiği mod olan denizyolu taşımacılığındaki lojistik süreçlerin etkin ve verimli bir biçimde koordine edilmesi, karmaşık bir yapıyı barındırdığından önemli olmaktadır. Bu sürecin iyi yönetilmesi ile aksaksız bir biçimde sürecin işlemesi mümkündür. Bu kapsamda çalışmada ülkelerin ekonomisinde önemli bir rol oynayan ihracat yüklerinin denizyolu taşıma süreci ele alınmıştır. FOB teslim şekli kapsamında ihracatçının sorumluluğu göz önüne alınarak, geminin bordasına kadar olan sürecin analizi yapılmıştır. Bu kapsamda ihracat yükleri için geminin bordasına kadar olan tüm süreçler ortaya konmuş, her bir sürecin olası süreleri belirlenmiş ve PERT Simülasyon kullanılarak toplam süre, kritik faaliyetler ve bolluklar ele alınmıştır.

Anabtar Kelimeler: Denizyolu Lojistiği, İhracat Süreci, PERT, Monte Carlo Simülasyonu.

\section{Process Analysis in Maritime Logistic Export with PERT Simulation}

\section{Abstract}

Effective and efficient coordination of logistics processes in maritime transport, which is the most intensive mode of international trade is crucial as it involves complex structure. A good management of this process results in running the process smoothly. In this context, this study examines the maritime transport process of export cargo, which plays a key role in the economy of the countries. The analysis of the process till the ship board has been made, taking into account the responsibility of the exporter within the scope of FOB delivery method. In this regard, all the processes up to the ship's board for export cargoes were revealed, the possible durations of each process were determined and the total time, critical activities and abundances were discussed applying PERT Simulation.

Key Words: Maritime Logistics, Export Process, PERT, Monte Carlo Simulation.

\section{Atıf İçin / Please Cite As:}

Bayar, S. ve Akan, E. (2021). PERT simülasyon yöntemiyle denizyolu lojistiği ihracat süreç analizi. Manas Sosyal Araștırmalar Dergisi, 10(2), 1053-1069.

Geliş Tarihi / Received Date: 01.11.2020

Kabul Tarihi / Accepted Date: 14.01.2021

\footnotetext{
1 Dr. Öğr. Üyesi, İstanbul Üniversitesi-Cerrahpaşa, Mühendislik Fakültesi, sibelb@istanbul.edu.tr

(D) ORCID: 0000-0002-9169-935X

2 Dr. Öğr. Üyesi - İskenderun Teknik Üniversitesi, Barbaros Hayrettin Gemi İnşaatı ve Denizcilik Fakültesi, ercan.akan@iste.edu.tr 


\section{Giriş}

Küreselleşen dünyada sınırlar yakınlaşmış olup, alıcılar nihai ürün, hammadde veya yarı mamul vb. ihtiyaçlarını karşılamak için başka bir ülkeden mal ithal edebilmekte veya ürünlerini başka bir ülkeye ihraç edebilmektedirler. İhraç taşımaları üreticinin pazarını genişletmesine imkân sunmakla beraber ülke ekonomisi açısından da önemli olmaktadır. Bu nedenle ülkelerin ithalat/ihracat politikaları bulunmakta ve ihracatını geliştirmesi için bazı teşvik ve önlemler alınabilmektedir.

Ülke ekonomisi açısından öneminin yanı sıra uluslararası taşımalar, gümrükleme sürecinden dolayı ulusal taşımacılığın aksine daha karmaşık bir yapıya sahip bulunmaktadır. Bu karmaşık doğası gereği, taşıma sürecinin lojistiği önem arz etmektedir. Ayrıca dünya ticaretinin tahminen \%80'i denizyolu ile taşınmakta olup (UNCTAD, 2020, s. 106); 2019 yllında ülkemizdeki ihracat taşımalarının \%60,3’ü ve ithalat taşımalarının da \%53,7'si denizyolu ile gerçekleştirilmiştir (T.C. Ticaret Bakanlığı, 2020). Ana hatlarıyla bakacak olursak; uluslararası denizyolu taşımacıllı̆ında gönderici yani ihracatçı firma, mallarını taşıtmak için bir lojistik firma veya freight forvarder ile anlaşmakta ve malları alıcı yani ithalatçı firmaya göndermektedir. Gönderici ve alıcı taşımaya başlamadan önce, INCOTERMS teslim şeklinden birine göre anlaşarak bir sözleşme imzalamakta ve bu sözleşme ile gönderici ve alıcının taşımadaki sorumlulukları belirlenmektedir. Çalışma bu INCOTERMS teslim şekillerinden biri olan FOB (Free On Board) (Gemide Masrafsız Teslim) teslim şekline göre incelenmiş ve göndericinin sorumluluğu açısından ele alınmıştır. Bu kapsamda; FOB teslim şekline göre ana nakliye sorumluluğu alıcıya aittir. Ancak geminin bordasına kadar olan bütün süreçlerin sorumluluğu ise göndericiye aittir (Piltz, 2020 s. 11).

Dolayısıyla; çalışmada denizyolu lojistiği ihracat sürecinin analizi yapılmıştır. Denizyolu lojistiği, denizyolu operasyonundaki tüm süreçlerin etkin bir şekilde planlanması, yönetilmesi ve uygulaması olmakla birlikte; tüm süreçlerin ortaya konulup, bu süreçlerin sürelerini, kritik faaliyetleri, bollukları hesaplaması ile hem etkin bir zaman yönetimi sağlanacak hem de olası aksaklık ve sıkışıklıkların önüne geçilecektir. Bu kapsamda; denizyolu lojistiğinde faaliyet gösteren bir lojistik işletmesinin denizyolu ihracat sürecine ait tüm faaliyetler ve bu faaliyetlerin PERT (Proje Değerlendirme ve Gözden Geçirme Tekniği) süreleri belirlenmiştir. Ayrıca; denizyolu lojistiğindeki ihracat sürecine ait faaliyetlerin birbirleriyle olan ilişkisi, bir diğer ifade ile faaliyetlerin öncül faaliyetleri belirlenmiştir. Sonuç olarak, PERT Simülasyon yöntemi kullanılarak denizyolu lojistiği ihracat sürecinin tamamlanma süresi, toplam iş yükü süresi ve kritik yolun tayininin analizi amaçlanmış olup, bu kapsamda önceki çalışmalardan ayrılmaktadır.

Deterministik yaklaşımların tersine, belirsizlik olduğu durumlarda olasılık temelli yaklaşımlar, karar verme problemlerinde daha başarılı sonuçlar vermektedir. Dolayısıyla bu çalışma için olasılık temelli yaklaşımın tercih edilmesinin nedeni, süreçlerin belirsizlik içermesi ve her bir yükün karakteristiğine bağlı olarak değişmesindendir. Ayrıca; PERT ve Monte Carlo simülasyon yöntemi ile daha geniş bir perspektif ile problem çözümü amaçlanmıştır.

Çalışmanın bundan sonraki bölümünde denizyolu lojistiğindeki ihracat süreci, simülasyon ve PERT tekniği ile ilgili literatürlere değinilmiştir. Ardından denizyolu lojistiğinde ihracat süreci konusu, metodoloji başlı̆̆ altında PERT tekniği, Monte Carlo simülasyonu ve denizyolu lojistik ihracat süreci uygulaması anlatilmaktadir.

\section{Literatür}

Öncelikle denizyolu ihracat lojistik süreçleri ile ilgili yapılan çalışmalara bakacak olursak; Chávez vd (2020) Büyük Ticaret Çöküşü sırasında Peru'daki bir ihracat sübvansiyon programının etkisini tahmin etmişlerdir. Buna göre tarihsel olarak, Perulu firmalar ihracatın FOB değeri için yüzde beş sübvansiyona erişmiş olup, kriz sırasında oranın yüzde 8'e çıktığını görmüşlerdir. Jouili (2019) özellikle ülkelerin mal ihracatı ile kalite lojistik performansı, liman altyap1 kalitesi ve liner nakliye bağlantısı arasındaki ilişkiyi araşıtımıştır. Sonuçlar, liman altyapısının kalitesinin, gümrük işlemlerinin yanı sıra ihracat ve deniz bağlantılarının süresinin ülkelerin mal ihracatını açıklayıcı faktörler olabileceğini göstermektedir. Jiang vd (2018) ise, Deniz İpek Yolu'nun beş nakliye güzergahında VAR modeli ile navlun oranı ile ihracat ticareti arasındaki korelasyonları incelemişlerdir. Ampirik sonuçlar, Basra Körfezi rotası ve Avrupa rotası üzerindeki beş rotadaki ihracatın navlun endeksi üzerinde önemli ölçüde olumsuz bir etkiye sahip olduğunu göstermektedir. Ayrıca; Güneydoğu Asya rotası ve Tayvan rotası navlun endeksinin ihracatı önemli ölçüde olumsuz etkilediği de görülmüştür.

Guarnaschelli vd. (2017) Şili'deki bir işletmenin odun ürünü ihracat sürecini destekleyen bir karar destek sistemi tasarımı için bir yaklaşım sunmayı amaçlamışlar ve bu kapsamda maliyeti en aza indirmeye 
ve daha iyi bir küresel hizmet seviyesi elde etmeye odaklanmışlardır. Hämäläinen vd. (2017), bir tedarik zincirinde toplam maliyeti analiz etmektedir. Üretiminin büyük bir çoğunluğunu Avrupa pazarına ihraç eden bir fabrikanın en büyük pazarına gönderilen 929 faturalı siparişe ait veriler kullanılmıştır. Bununla birlikte; Manova ve Zhang (2012) Çin ticaret akışlarının evrenine ilişkin ayrıntılı gümrük verilerini kullanarak, firmaların ihracat fiyatlarını incelemişlerdir. Pérez-Mesa vd. (2012) ise, ihraç meyve ve sebzeler için intermodal taşımacılıkta kısa deniz taşımacılığını kullanmanın faydalarını tartışmaktadırlar. $\mathrm{Bu}$ kapsamda çok kriterli karar verme teknikleri; çevresel dışsallıklar da dâhil olmak üzere arazi ve intermodal taşımacılık arasındaki en uygun tahsisi belirlemek için uygulanmıss ve bir duyarlılık analizi de yapılmıstır.

Chen ve Yang (2010), terminal ve kamyon teslimat işlemlerini kolaylaştırmak için; Çin terminallerinde yaygın olarak kullanılan bir zaman aralığı yönetim programına dayalı olarak, ihracat konteynerlerinin kamyon trafiğini yönetmenin etkili bir yolunu araştırmışlardır. Lee ve Chao (2009), ihracat konteynerlerinin yerleşimini iyileştirecek bir hareket planı geliştirmek için bir model önermişlerdir. Önerilen buluşsal yöntem, bir mahalle arama süreci, bir tamsayı programlama modeli ve üç küçük alt yordamdan oluşmaktadır. Kang vd (2006) belirsiz ağırlık bilgisine sahip ihracat konteynerleri için iyi bir istifleme stratejisi elde etmek amacıyla; benzetilmiş tavlama araştırmasına dayalı bir yöntem önermişlerdir. Simülasyon deneyleri, çalışmada önerilen stratejilerin, geleneksel aynı ağıllıkta grup istifleme stratejisine göre yeniden işleme sayısını daha etkili bir şekilde azalttığını göstermiştir.

Erera vd (2003) ABD ve Singapur ihraç konteyner deniz kargo süreçlerinin bir arka plan çalışmasını sunmaktadırlar. Mevcut süreçleri anlayarak ve karşılaştırarak, verimlilik ve maliyetten ödün vermeden, daha güvenli bir tedarik zinciri ağ1 tasarlamak amaçlanmıştır. Kim vd (2000) ihracat konteynerinin ağırlı̆̆ına göre depolama yerini belirlemek için bir metodoloji önermektedirler. Çalışmada, yükleme işlemi için beklenen yer değiştirme hareketlerinin sayısını en aza indirmek için depolama konumunu belirlemek üzere dinamik bir programlama modeli formüle edilmiştir. Tongzon (1989) Avustralya'nın ihracat endüstrileri için genel nakliye zincirinde iskele ücretlerinin rolünü değerlendirmiş ve eğer varsa, Liman üzerinden ticaret üzerindeki etkilerini ve rıhtım maliyetlerindeki (yani kargo temelli) bir azalmanın refah üzerindeki etkilerini ölçmeyi amaçlamıştır. Bununla birlikte; Tahar ve Hussain (2000) limandaki lojistik süreçleri iyileştirmek amacıyla limanı işletmek için gerekli tüm süreçleri performansı en üst düzeye çıkarmak içim simüle etmişlerdir. Bayar ve Akan (2020) ise denizyolu lojistiğinde fiyatlandırma sürecindeki faaliyetleri tanımlayarak, bulanık simülasyon yöntemi ile sürecin analizini yapmışlardır.

Rahardianto vd (2018) konteyner terminalinin performans zaman değerlendirmesini veri madenciliği ve PERT kullanarak analiz etmişlerdir. Performans değerlendirmesi ile, özellikle yükleme ve boşaltma olmak üzere her bir süreci ve Terminal İşletim Sistemi (TOS) sisteminde kaydedilen olay günlüğünü analiz etmişlerdir. Servis süresinin optimize edilmesi, olay günlügünün Alpha ve PERT Algoritmaları kullanılarak analiz edilmesiyle gerçekleştirilmiştir. Uddin ve Jinia (2017) geleneksel hızlandırma yönteminin, sadece kritik yolun hesaplanması için ortalama faaliyet sürelerini dikkate almasından ve faaliyet süresinin stokastik yapısını göz ardı etmesinden dolayı; PERT'i değerlendirmek için stokastik bir simülasyon yapmışlar ve farklı simülasyon uzunluklarında proje tamamlama sürelerinin frekanslarını hesaplamışlardır. Belirli bir tamamlanma süresine ulaşılırken gerekli maliyeti en aza indirgemek amacıyla projeyi hızlandırmak için doğrusal bir program geliştirmişlerdir. Bruzzone vd (2012) her geminin liman bölgesinde geçirdiği ortalama sürenin en aza indirilmesini amaçlayan konteyner terminali simülasyon modeli geliştirmişleridir. İlk olarak Deney Tasarımı ve Varyans Analizi ile birlikte farklı kaynak tahsislerinin ve bazı parametrelerin konteyner terminal performansları üzerindeki etkilerini günlük toplam elleçlenen konteyner sayısı açısından incelenmiştir. Ardından, Deney Tasarımı ve Varyans Analizi ile elde edilen sonuçlara dayanarak, simülasyon modeli, gelen gemilere rihtım ataması ve her rihtım vincine hizmet veren traktör sayısı konusunda bir menzil tahsis optimizasyonu gerçekleştirmek için genetik algoritmalarla birlikte kullanılmıştır.

Son olarak simülasyon ve PERT ile ilgili yapılan çalışmalara baktığımızda ise; Tenjo-García ve Figueroa-García (2019), bulanık aktivite sürelerine sahip PERT problemlerini çözmek için simülasyon tabanlı bir yöntemi kullanmışlardır. Önceki bulanık simülasyon tekniklerine dayanarak, farklı zaman etkinliği kombinasyonlarına bağlı olası kritik yolların farklı senaryolarını simüle etmişlerdir. Karabulut (2017) ise, orta ölçekli bir inşaat firmasında bir proje yürütme takip sistemini incelemiş ve proje çizelgeleme ve izleme için iki farklı yöntem önermiştir. Çalışmada geleneksel CPM ve PERT yöntemleri ve risk analiz aracı olarak Monte Carlo simülasyonu kullanılmıştır. Ayrıca; Aghaie ve Mokhtari (2009), belirsizlikler altında proje hızlandırma problemi için karınca kolonisi optimizasyonu meta sezgisel ve 
Monte Carlo simülasyon tekniğine dayalı yeni bir yaklaşımı açıklamaktadırlar. PERT türü ağlarda, etkinliklerin ayrı maliyet işlevlerine tabi tutulduğu ve katlanarak dağıtılacağı varsayıldığı, güven düzeyine dayalı bir yaklaşım önerilmiştir. Bowman (1994) ise; PERT ağları için sonsuz küçük pertürbasyon analizi ve puan fonksiyonu gradyan tahmin edicileri geliştirmiştir. Badiru (1991), simülasyonu proje ağ analizi için yararlı bir analitik araç olarak sunmaktadır. STARC adlı bir bilgisayar programı, proje planlaması için bilgisayar simülasyonunun etkinliğini göstermek için kullanmıstır. STATGRAPHICS yazılımı, gerçekleştirilebilecek bazı simülasyon sonrası istatistiksel analizleri göstermek için kullanılmıştır.

Bu çalışma, PERT tekniğinin simülasyon ile beraber kullanımının denizyolu lojistiğindeki uygulaması açısından literatüre katkı sağlamaktadır.

\section{Denizyolu Lojistiğinde İhracat Süreci}

Denizyolu lojistiği, deniz taşımacılı̆̆ (nakliye ve limanlar), geleneksel lojistik işlevler (depolama, dağıtım merkezi hizmetleri sunma vb.) ve entegre lojistik faaliyetler (etiketleme, montaj, onarım dahil katma değerli hizmetler vb.) ile ilgilidir (Nam ve Song, 2011 s. 273). Deniz taşımacılığının temel işlevi; göndericilerin yüklerini bir limandan diğer bir limana taşınmasıdır. Bu temel işlevi gerçekleştirmek için yükün gemiye yüklenmesinden, varış limanında yüklerin boşaltılıp araca yüklenerek limandan çıkışına kadar olan bütün iş süreçlerinin planlanması, gerçekleştirilmesi ve yönetimi ise deniz lojistiği olarak ifade edilmektedir. Dolayısıyla denizyolu lojistiğinde temel mesele, fiziksel (intermodal, multimodal), ekonomik/stratejik (dikey entegrasyon, yönetim yapısı) ve organizasyonel seviyede (ilişki tabanlı, personel ve süreç entegrasyonu) entegrasyonu sağlamaktır (Çalışkan ve Öztürkoğlu, 2018 s. 363). Bu kapsamda denizyolu lojistik süreci Şekil 1'deki gibi gösterilmektedir (Lee ve Song, 2010 s. 567).

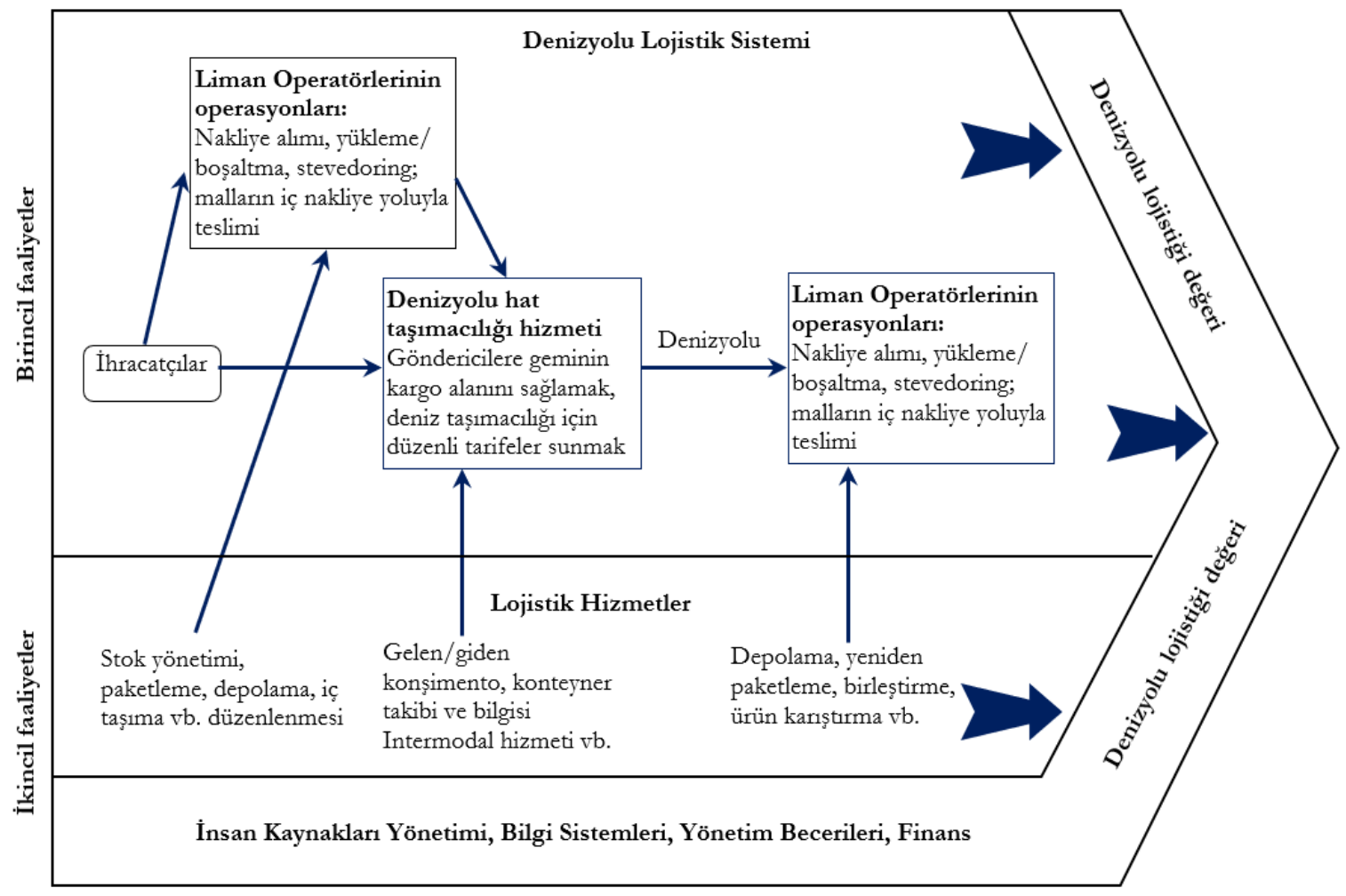

Şekil 1. Deniz Lojistike Süreci (Lee ve Song, 2010 s. 567).

Denizyolu lojistiği genellikle; okyanus taşımacıllı̆ının dahil olduğu malların ve bilgilerin hareketini planlama, uygulama ve yönetme süreci olarak adlandırllır. Bu tanım; özellikle deniz taşımacılığının küresel lojistik ve tedarik zincirlerindeki rolünü ve lojistik entegrasyon sistemindeki stratejik olarak önemli rolünü vurgulamaktadır (Nam ve Song, 2011 s. 275). Bu kapsamda Branch'ın tanımına göre; "uluslararası ticaret, iki veya daha fazla ülke arasında, iki veya daha fazla ülkenin kullanımını içeren, mal veya hizmet alışverişi sürecidir” (Branch, 2006 s. 3). Bununla birlikte; uluslararası ticaret, kendi ülkendeki malların satımı (dıs satım) olarak ifade edilen ihracat ve başka ülkeden mal alımı (dış alım) olarak ifade edilen ithalat faaliyetlerinden meydana gelmektedir. İthalat ve ihracat yüklerinin süreçleri temelde aynı görünse de özellikle gümrükleme sürecinde birbirinden ayrilmaktadır. 
Denizyolu taşımacıllı̆ında gönderici (ihracatçı), yükleri genellikle bir lojistik firma veya freight forvarder aracıllğıyla alıcıya (ithalatçı) göndermektedir. Aralarındaki INCOTERMS'e (uluslararası teslim şekli) göre gönderici ve alıcının sorumlulukları belirlenmektedir. INCOTERMS, teslim şekline göre satıcı ve alıcı arasındaki sorumluluğu belirten standart olarak kalıplaștırılmıș uluslararası taşımada kullanılan anlaşmalar olarak düşünülebilir. En son güncelleştirilmiş hali ile INCOTERMS 2020; E, F, C ve D grubu olarak 4 ana grup altında toplanmıştır. Bu sıraya göre, satıcının sorumluluğu gittikçe artarken; alıcının sorumluluğu ise gittikçe azalmaktadır. Dolayısıyla; E grubunda alıcının sorumluluğu en yüksek, satıcının sorumluluğu en düşük iken; D grubunda ise alıcının sorumluluğu en düşük, satıcının sorumluluğu ise en yüksek olduğu taşıma şekillerini içeren grubu temsil etmektedir. Bu kapsamda bu grupların içeriği Tablo 1'deki gibidir. Tablo 1'de görüldüğ̈u gibi taşıma şekline göre ihracat ve ithalatçının sorumluluğu ve süreçler değişmektedir (Piltz, 2020 s. 11-12).

Bu kapsamda çalışmada FOB taşıma şekline göre bir deniz lojistiği ihracat süreci incelenmiş ve Beta dağılımı kullanılarak simüle edilerek kritik faaliyetler tespit edilmiştir. Tablo 1'de de görüldüğü üzere; FOB (Free On Board) taşıma şeklinde, malların ana nakliyesinden alıcı sorumludur. Ancak; satıc1, malları belirtilen teslim yerine nakletmek ve koşullara bağlı olarak bunları yüklemek ve masrafları kendisine ait olmak üzere ihracat için gümrükten geçirmekle yükümlüdür (Piltz, 2020 s. 11). Bu kapsamda kontrol, paketleme, markalama, ihracat prosedürleri ve yükleme yükümlülüğü satıcıda olup; taşıma, boşaltma ve ithalat prosedürlerinin yükümlülüğ̈ ise alıcıya aittir. Satıcının alıcıya karşı sigorta sözleşmesi yapma yükümlülüğü ise bulunmamaktadır (Utikad, 2020 s. 23).

Tablo 1. INCOTERMS 2020 Tassma Şekilleri (Pilts, 2020 s. 11-12)

\begin{tabular}{|c|c|c|}
\hline Grubu & Taşıma Şekli & Sorumluluk \\
\hline $\mathrm{E}$ & EXW - Ex Works (İş yerinde Teslim) & $\begin{array}{l}\text { Malların nakliyesi ve ihracat gümrükleme dahil gümrük } \\
\text { işlemleri alıcıya aittir. }\end{array}$ \\
\hline $\mathrm{F}$ & $\begin{array}{l}\text { FCA - Free Carrier (Taşıyıcıya Masrafsız Teslim), } \\
\text { FAS - Alongside Ship (Gemi doğrultusunda } \\
\text { Masrafsız Teslim, } \\
\text { FOB - Free On Board (Gemide Masrafsız Teslim) }\end{array}$ & $\begin{array}{l}\text { Malların ana nakliyesinden alıcı sorumludur. Ancak, satıcı } \\
\text { malları belirtilen teslim yerine nakletmek ve koşullara bağlı } \\
\text { olarak bunları yüklemek ve masrafları kendisine ait olmak } \\
\text { üzere ihracat için gümrükten geçirmekle yükümlüdür. }\end{array}$ \\
\hline $\mathrm{C}$ & $\begin{array}{l}\text { CFR - Cost and Freight (Masraflar ve Navlun } \\
\text { Dahil Teslim) } \\
\text { CIF - Cost Insurance and Freight (Masraflar, } \\
\text { Sigorta ve Navlun Dahil Teslim) } \\
\text { CPT - Carriage Paid To (Taşıma Ücreti Ödenmiş } \\
\text { Olarak Teslim) } \\
\text { CIP - Carriage and Insurance Paid To (Taşıma } \\
\text { Ücreti ve Sigorta Ödenmiş Teslim) }\end{array}$ & $\begin{array}{l}\text { Tüm C maddelerinin ortak bir özelliği olarak, satıcı malları } \\
\text { ihracat için gümrükten geçirmeli ve F grubundan farklı } \\
\text { olarak belirtilen varış yerine nakliyeyi masrafları kendisine } \\
\text { ait olacak şekilde ayarlamalıdır. F maddelerinin aksine, alıc1 } \\
\text { malları teslimat yerinde değil, sadece belirtilen varış yerinde } \\
\text { devralmak zorunda kalır. Ancak F grubunda olduğu gibi, } \\
\text { mallar teslimat yerinde taşıyıcıya teslim edilir edilmez riskler } \\
\text { alıciya geçer. }\end{array}$ \\
\hline $\mathrm{D}$ & $\begin{array}{l}\text { DAP - Delivered at Place } \\
\text { DPU - Delivered at Place Unloaded } \\
\text { DDP - Delivered Duty Paid }\end{array}$ & $\begin{array}{l}\text { Satıcı tüm masrafları ve } \mathrm{C} \text { maddelerinin aksine, mallar } \\
\text { belirtilen varış yerine ulaşana kadar tüm riskleri karşılar. } \\
\text { Ancak, malların ithalat için gümrükten çekilmesinden alıcı } \\
\text { sorumludur }\end{array}$ \\
\hline
\end{tabular}

\section{Metodoloji}

\section{PERT Tekniği}

PERT tekniği, proje yönetiminde yer alan görevleri analiz etmek, temsil etmek, planlamak ve kontrol etmek için tasarlanmış, proje yönetiminde kullanılan istatistiksel bir yöntemdir. Genel olarak PERT yöntemi, beklenen süre hesaplama, ileriye doğru hesaplama, geriye doğru hesaplama, boşluk sürelerinin hesaplaması ve kritik yolun tayini ile özetlenir. Genel olarak PERT tekniği, aşağıda Denklem (1-6) gibi tanımlanmaktadır (Malcolm vd., 1959; Cottrell, 1999; Pontrandolfo, 2000).

$$
\begin{aligned}
& t_{e}=\left(\frac{a+4 m+b}{6}\right) \\
& \sigma^{2}=\left(\frac{b-a}{6}\right)^{2} \\
& E S_{i}=\max _{v_{j} \in P_{i}}\left[E S_{j}+A_{j}\right]
\end{aligned}
$$




$$
\begin{aligned}
& E F_{i}=E S+A_{i} \\
& L F_{i}=\min _{v_{j} \in S_{i}}\left[L F_{j}-A_{j}\right] \\
& L S_{i}=L F_{i}-A_{i}
\end{aligned}
$$

Burada;

$$
\begin{array}{ll}
t_{e} & \text { beklenen süre, } \\
a & \text { iyimser süre, } \\
m & \text { kötümser süre, } \\
b & \text { en olasi süre, } \\
\sigma^{2} & \text { varyans, } \\
E S_{i} & i . \text { faaliyete göre erken başlama, } \\
E F_{i} & i . \text { faaliyete göre erken tamamlama, } \\
L S_{i} & i . \text { faaliyete göre geç başlama, } \\
L F_{i} & i . \text { faaliyete göre geç tamamlama, } \\
A_{j} & j . \text { faaliyetin süresi } \\
v_{j} & j . \text { faaliyet } \\
P_{i} & j . \text { faaliyetin öncülü } \\
S_{i} & j . \text { faaliyetin ard1lı }
\end{array}
$$

olmaktadir.

\section{Monte Carlo Simülasyonu}

Belirsizlik altında zor ve karmaşık problemleri çözmek için; olasılık yoğunluk fonksiyonları tesadüfi değişkenlerle örneklenmesini kullanan bir yöntem olan Monte Carlo simülasyon tekniği, stokastik optimizasyon yöntemleri içinde sıklıkla kullanılan bir tekniktir. Monte Carlo simülasyonu, diğer alanlarda olduğu gibi işletme yönetimi açısından da Pazar araştırmasından stratejik planlamaya, finanstan operasyon süreçlerine kadar geniş bir alanda yapılan çalışmalarda yaygın olarak kullanılmaktadır.

Yöntem, bir $f$ fonksiyonunun integralini belirlemek için çok boyutlu bir hacimden $V \quad N$ tane rasgele dağıtım noktalarını $x_{1}, x_{2}, x_{3}, \ldots, x_{N}$ seçmek için bir sonuç vermektedir. Burada temel problem, (Denklem 7-9)'da belirtildiği gibi çok boyutlu integral ile tahmin edilmesidir (Ueberhuber, 1997 s. 124-138; Bayar ve Akan, 2020 s. 29).

$$
I=\int f d V \approx V(f) \pm V \sqrt{\frac{\left(f^{2}\right)-(f)^{2}}{N}}
$$

Burada;

$$
\begin{aligned}
& (f)=\frac{1}{N} \sum_{n=1}^{N} f\left(x_{i}\right) \\
& \left(f^{2}\right)=\frac{1}{N} \sum_{n=1}^{N} f^{2}\left(x_{i}\right)
\end{aligned}
$$

\section{Beta Dağılım Fonksiyonu}

Standart Beta dağılımı, [0,1] kapalı aralığında bir $x$ değerinin olasılık aralı̆̆ında tanımlanan sürekli bir dağılım göstermekte olup; olasılık yoğunluk fonksiyonu (probability density function - pdff) Denklem (10-11) aşağıda gösterilmektedir (Johnson vd., 1994; Brandimarte, 2014; Vose, 2008). Olasılık dağılım fonksiyonun dağılımı, iki parametreye bağlıdır. Bunlar; $\alpha, \beta>0$ olarak tanımlanır.

$$
\operatorname{Beta}(\alpha, \beta): \operatorname{prob}(x \mid \alpha, \beta)=\frac{x^{\alpha-1}(1-x)^{\beta-1}}{B(\alpha, \beta)}, x \in[0,1], \min \leq x \leq \max , \min <\max
$$




$$
B(\alpha, \beta) \equiv \int_{0}^{1} x^{\alpha-1}(1-x)^{\beta-1} d x
$$

Burada B, Beta fonksiyonudur.

\section{Simülasyonda Tekrar Sayısı}

Simülasyon, rasgele sayılar ile belirsiz koşullar altında çözüm gerçekleştirdiğinden dolayı, deterministik yöntemlerdeki gibi kesin bir sonuç vermemektedir. Bu nedenle bir tek tekrarsız olarak bulunan çözümü cevap olarak kabul etmek mümkün değildir. Simülasyon kesin bir sonuç vermemekle birlikte; belli güven aralı̆̆ında ve belli bir hata payı dikkate alınarak en az kaç iterasyonla doğru sonuca ulaşacağımızı tahmin edebilmeye olanak tanımaktadır. Bu kapsamda gerekli tekrar sayıs1 Denklem (12)'deki gibi hesaplanmaktadır (Hahn, 1972:679; Bayar ve Akan, 2020:30).

$$
n=\left(\frac{z_{(1+\gamma) / 2} \sigma^{\prime}}{E}\right)^{2}
$$

Burada;

$$
\begin{array}{ll}
n & \text { deneme sayısı } \\
\sigma^{\prime} & \text { başlangıç tahmini popülasyonun standart sapması } \\
E & \text { en fazla kabul edilebilir hata payı } \\
z_{(1+\gamma) / 2} & \text { güven aralığının normal dağıllım tablosundaki değeri }
\end{array}
$$

olarak ifade edilir.

\section{Lojistik Denizyolu İhracat Konteyner Süreci Uygulama}

Deniz lojistiğinde birçok faaliyet bulunmaktadır. Denizyolu ihracat süreci de pek çok faaliyetin birlemişinden oluşmaktadır. Bu çalışmada denizyolu ihracat lojistiğindeki süreç analizi PERT Simülasyon yöntemiyle yapılmıştır. Uygulama; FOB yükleme temelinde dikkate alınmıştır.

Satıcı olan ihracatçı firma, öncelikle bir lojistik firma ile anlaşarak taşıma işini yaptırır. FOB taşıma şekli kullanılması durumunda; ilgili firma satıcının sorumluluklarını üstlenmekte, bu taşıma sürecinde tüm lojistik işlemlerini gerçekleştirilmesine hizmet etmektedir. $\mathrm{Bu}$ kapsamda çalışmada, satıcının sorumluluğundaki süreçler ele alınmıştır.

Tablo 2'de, denizyolu ihracat operasyonu sürecinin faaliyetlere ayrıştırılmış şekli belirtilmiştir. Uygulamada, denizyolu lojistik ihracat departmanının operasyon sürecinin genel bir şekli incelenmiştir. Denizyolu ihracat operasyon süreci, PERT tekniği metoduna uygun olacak şekilde faaliyetlere ayrıştırlmış, operasyon faaliyetleri arasındaki ilişkiler belirlenmiş ve faaliyetlerin PERT süreleri dakika olarak atanmıştır. Uygulama, uluslararası alanda faaliyet gösteren bir lojistik firmasında yapılan gözlem sonucunda oluşturulan operasyon proses analizi çerçevesinde oluşturulmuş olup; genel bir süreci açıkladığından, bütün bu işlemler genel olarak bir denizyolu ihracat sürecini içermektedir. 
Tablo 2. Denisyolu ibracat faaliyetler

\begin{tabular}{|c|c|}
\hline No & Faaliyet \\
\hline E1 & Faaliyetlere başlamak \\
\hline E2 & Müşteri ile iletişime geçilmesi \\
\hline E3 & Denizaşırı ofisle yükleyici ve yük detaylarının temini ve teyidi \\
\hline E4 & Yükleyiciden yükün teyidinin alınması \\
\hline E5 & Denizaşırı ofise teyit mesajı, maliyet bildirimi ve teyidi \\
\hline E6 & Yükleyiciye yükleme teyit mesajı verilerek yükleme detaylarının temin edilmesi \\
\hline E7 & Armatörün gemi bilgilerini sağlaması \\
\hline E8 & Yükleyiciye ve gümrükçüye gemi detaylarının gönderilmesi \\
\hline E9 & Yükleyiciden gemi için rezervasyon teyidinin alınması \\
\hline E10 & Rezervasyon \\
\hline E11 & Armatörden rezervasyon onayı ve detayların temini \\
\hline E12 & Müşteriye rezervasyon teyidi \\
\hline E13 & Müşteriden yükleme yerinin ve gününün teyidinin alınması \\
\hline E14 & Tedarikçiden, iç taşıma fiyat teklifinin alınması ve tedarikçinin seçiminin kararı \\
\hline E15 & Tedarikçiye depo, yükleme adresi bilgilerinin iletilerek araç ve konteyner bilgilerinin alınması \\
\hline E16 & Yükleyiciye araç detaylarının bildirilmesi \\
\hline E17 & "Yükleme tamamlandı" bilgisinin teyidi \\
\hline E18 & Müşteriden yükleme talimatın temin edilmesi \\
\hline E19 & Armatöre yükleme talimat hazırlanması ve gönderilmesi \\
\hline E20 & ESYS'de JOB düzenleme arayüzüne giriş ve JOB oluşturulması \\
\hline E21 & Armatörle liman giriş kapı kaydı kontrolü \\
\hline E22 & Beyanname teslimi kontrolü \\
\hline E23 & Gelir faturası için satış tutarlarının temini \\
\hline E24 & Gider faturası için maliyet tutarlarının temini \\
\hline $\mathrm{E} 25$ & ESYS'de gelir ve gider faturası rezervleme \\
\hline E26 & Kar/Zarar kontrolünün yapılması \\
\hline E27 & ESYS'de JOB taslak B/L hazırlama \\
\hline E28 & Taslak B/L basılması ve taslak B/L taranması \\
\hline E29 & Line taslak B/L temini \\
\hline $\mathrm{E} 30$ & Taslak B/L müşteriye gönderilmesi ve müşteriden $\mathrm{B} / \mathrm{L}$ düzenlenmek için teyit maili alınması \\
\hline E31 & Line taslak B/L kontrolü ve teyidi \\
\hline E32 & Geminin kalkışının teyidi \\
\hline E33 & ESYS'de JOB güncellemesi \\
\hline E34 & Orijinal ya da 1060xpress B/L basımı ve kaşeleme, imzalama, kopyalama, dosyalama, kargo \\
\hline E35 & Geminin kalkışının müşteriye bildirilmesi \\
\hline E36 & ESYS'de gelir faturası düzenleme, imzalama, nüshaları ayrıştırma ve dosyalama \\
\hline E37 & A-META \\
\hline E38 & Müşteriden mal faturası, çeki listesi, vb. temin edilmesi \\
\hline E39 & eMpower güncelleme \\
\hline E40 & HBL, MBL, mal faturası, çeki listesi, vb. taranması, evraklarını ESF'e ekleme ve e-mail yoluyla bildirimi \\
\hline E41 & ESYS'de gider faturasının Job ID belirleme ve ESYS'de JOB gider kontrolü (eğer doğru ise) \\
\hline E42 & Yöneticiye fatura onay imzalama \\
\hline E43 & Gider faturası kopyalama ve muhasebeye verilmesi ve fatura kopyasının dosyalanması \\
\hline E44 & Faaliyetlileri bitirmek \\
\hline
\end{tabular}

Tablo 3'de denizyolu ihracat sürecine ait ilgili faaliyetlere ait öncüller ile PERT süre değerleri dakika olarak verilmiştir. Her bir faaliyet için verilen bu değerler, PERT hesaplanmasında ve PERT simülasyonunda kullanılmıştır. 
Tablo 3. Denizyolu ihracat faaliyetlerin süreleri (dakika) ve öncülleri

\begin{tabular}{|c|c|c|c|c|}
\hline Faaliyet & Öncüller & $\dot{I}_{\text {yimser Süre (a) }}$ & Olas1 Süre (m) & Kötümser Süre (b) \\
\hline E1 & - & 1,0 & 1,5 & 2,0 \\
\hline E2 & E1 & 2,5 & 4,0 & 5,5 \\
\hline E3 & E1 & 6,5 & 9,0 & 11,0 \\
\hline E4 & E2 & 6,0 & 9,0 & 13,5 \\
\hline E5 & E3 & 7,0 & 10,5 & 14,0 \\
\hline E6 & E4, E5 & 6,0 & 8,5 & 10,5 \\
\hline E7 & E1, E6 & 3,0 & 6,0 & 10,5 \\
\hline E8 & E6, E7 & 1,5 & 2,5 & 3,0 \\
\hline E9 & E8 & 1,5 & 3,5 & 5,0 \\
\hline E10 & E7, E9 & 2,0 & 3,5 & 5,5 \\
\hline E11 & E10 & 2,0 & 4,5 & 8,0 \\
\hline E12 & E9, E11 & 1,5 & 2,0 & 2,5 \\
\hline E13 & E12 & 2,0 & 4,0 & 7,0 \\
\hline E14 & E13 & 4,5 & 6,5 & 10,0 \\
\hline E15 & E11, E14 & 2,0 & 2,5 & 3,5 \\
\hline E16 & E15 & 2,0 & 2,5 & 3,5 \\
\hline E17 & E16 & 1,5 & 2,5 & 4,0 \\
\hline E18 & E17 & 4,0 & 7,0 & 12,0 \\
\hline E19 & E11, E18 & 4,0 & 6,5 & 10,0 \\
\hline E20 & E18 & 4,5 & 7,0 & 11,0 \\
\hline E21 & E15 & 1,0 & 2,5 & 5,0 \\
\hline E22 & E19, E21 & 1,5 & 3,0 & 5,0 \\
\hline E23 & E9 & 1,5 & 3,5 & 5,5 \\
\hline E24 & E9 & 2,0 & 4,0 & 77,0 \\
\hline E25 & E20, E23, E24 & 3,5 & 6,0 & 9,0 \\
\hline E26 & E25 & 1,0 & 1,5 & 1,5 \\
\hline $\mathrm{E} 27$ & E20 & 4,0 & 6,0 & 10,5 \\
\hline E28 & E27 & 1,5 & 3,0 & 4,5 \\
\hline E29 & E19 & 1,5 & 3,5 & 7,0 \\
\hline E30 & E28, E29 & 3,0 & 5,0 & 8,0 \\
\hline E31 & $\mathrm{E} 30$ & 2,0 & 3,0 & 5,0 \\
\hline E32 & E22 & 2,0 & 3,5 & 6,5 \\
\hline $\mathrm{E} 33$ & E20, E32 & 2,0 & 3,0 & 5,5 \\
\hline E34 & E30, E32, E33 & 4,0 & 6,5 & 9,5 \\
\hline E35 & $\mathrm{E} 32$ & 1,5 & 2,0 & 2,5 \\
\hline E36 & E25, E32 & 6,5 & 10,5 & 14,0 \\
\hline E37 & $\mathrm{E} 25, \mathrm{E} 26$ & 1,0 & 2,0 & 2,5 \\
\hline E38 & E32 & 2,6 & 5,0 & 8,5 \\
\hline E39 & $\mathrm{E} 33$ & 2,5 & 5,0 & 10,0 \\
\hline E40 & E31, E34, E36, E38 & 6,0 & 9,5 & 14,5 \\
\hline E41 & $\mathrm{E} 25, \mathrm{E} 33$ & 4,0 & 6,5 & 9,0 \\
\hline E42 & E41 & 1,0 & 1,5 & 2,5 \\
\hline E43 & $\mathrm{E} 41, \mathrm{E} 42$ & 2,5 & 3,5 & 4,5 \\
\hline E44 & $\mathrm{E} 43, \mathrm{E} 40, \mathrm{E} 35, \mathrm{E} 37, \mathrm{E} 39$ & 1,0 & 1,5 & 2,0 \\
\hline
\end{tabular}

Tablo 4'de denizyolu ihracat sürecinde faaliyetlerin PERT süreleri, hesaplanmış varyansları ve beklenen zamanlar gösterilmiştir. Bu kısımda varyans değerlerinin sıfıra yakın olması durumunda, ilgili faaliyetteki belirsizliğin daha az olduğu düşünülebilir. Bu da ilgili faaliyette sürelerin daha tahmin edilebilir bir değerde olmasını sağlar. 
Tablo 4. Denizyolu ibracat faaliyetlerin Öncülleri ve PERT süreleri (dakika)

\begin{tabular}{|c|c|c|c|c|c|}
\hline Faaliyet & $\begin{array}{l}\text { Íyimser Süre } \\
\text { (a) }\end{array}$ & $\begin{array}{l}\text { Olas1 Süre } \\
(\mathrm{m})\end{array}$ & $\begin{array}{l}\text { Kötümser } \\
\text { Süre (b) } \\
\end{array}$ & Varyans & $\begin{array}{l}\text { Beklenen Zaman } \\
t_{e}\end{array}$ \\
\hline E1 & 1,0 & 1,5 & 2,0 & 0,03 & 1,5 \\
\hline E2 & 2,5 & 4,0 & 5,5 & 0,25 & 4,0 \\
\hline E3 & 6,5 & 9,0 & 11,0 & 0,56 & 8,9 \\
\hline E4 & 6,0 & 9,0 & 13,5 & 1,56 & 9,3 \\
\hline E5 & 7,0 & 10,5 & 14,0 & 1,36 & 10,5 \\
\hline E6 & 6,0 & 8,5 & 10,5 & 0,56 & 8,4 \\
\hline E7 & 3,0 & 6,0 & 10,5 & 1,56 & 6,3 \\
\hline E8 & 1,5 & 2,5 & 3,0 & 0,06 & 2,4 \\
\hline E9 & 1,5 & 3,5 & 5,0 & 0,34 & 3,4 \\
\hline E10 & 2,0 & 3,5 & 5,5 & 0,34 & 3,6 \\
\hline E11 & 2,0 & 4,5 & 8,0 & 1,00 & 4,7 \\
\hline E12 & 1,5 & 2,0 & 2,5 & 0,03 & 2,0 \\
\hline E13 & 2,0 & 4,0 & 7,0 & 0,69 & 4,2 \\
\hline E14 & 4,5 & 6,5 & 10,0 & 0,84 & 6,8 \\
\hline E15 & 2,0 & 2,5 & 3,5 & 0,06 & 2,6 \\
\hline E16 & 2,0 & 2,5 & 3,5 & 0,06 & 2,6 \\
\hline E17 & 1,5 & 2,5 & 4,0 & 0,17 & 2,6 \\
\hline E18 & 4,0 & 7,0 & 12,0 & 1,78 & 7,3 \\
\hline E19 & 4,0 & 6,5 & 10,0 & 1,00 & 6,7 \\
\hline E20 & 4,5 & 7,0 & 11,0 & 1,17 & 7,3 \\
\hline E21 & 1,0 & 2,5 & 5,0 & 0,44 & 2,8 \\
\hline E22 & 1,5 & 3,0 & 5,0 & 0,34 & 3,1 \\
\hline E23 & 1,5 & 3,5 & 5,5 & 0,44 & 3,5 \\
\hline E24 & 2,0 & 4,0 & 77,0 & 156,25 & 15,8 \\
\hline E25 & 3,5 & 6,0 & 9,0 & 0,84 & 6,1 \\
\hline E26 & 1,0 & 1,5 & 1,5 & 0,01 & 1,4 \\
\hline E27 & 4,0 & 6,0 & 10,5 & 1,17 & 6,4 \\
\hline E28 & 1,5 & 3,0 & 4,5 & 0,25 & 3,0 \\
\hline E29 & 1,5 & 3,5 & 7,0 & 0,84 & 3,8 \\
\hline E30 & 3,0 & 5,0 & 8,0 & 0,69 & 5,2 \\
\hline E31 & 2,0 & 3,0 & 5,0 & 0,25 & 3,2 \\
\hline E32 & 2,0 & 3,5 & 6,5 & 0,56 & 3,8 \\
\hline E33 & 2,0 & 3,0 & 5,5 & 0,34 & 3,3 \\
\hline E34 & 4,0 & 6,5 & 9,5 & 0,84 & 6,6 \\
\hline E35 & 1,5 & 2,0 & 2,5 & 0,03 & 2,0 \\
\hline E36 & 6,5 & 10,5 & 14,0 & 1,56 & 10,4 \\
\hline E37 & 1,0 & 2,0 & 2,5 & 0,06 & 1,9 \\
\hline E38 & 2,6 & 5,0 & 8,5 & 0,96 & 5,2 \\
\hline E39 & 2,5 & 5,0 & 10,0 & 1,56 & 5,4 \\
\hline E40 & 6,0 & 9,5 & 14,5 & 2,01 & 9,8 \\
\hline E41 & 4,0 & 6,5 & 9,0 & 0,69 & 6,5 \\
\hline E42 & 1,0 & 1,5 & 2,5 & 0,06 & 1,6 \\
\hline E43 & 2,5 & 3,5 & 4,5 & 0,11 & 3,5 \\
\hline E44 & 1,0 & 1,5 & 2,0 & 0,03 & 1,5 \\
\hline
\end{tabular}

Tablo 5'de denizyolu ihracat sürecinin klasik PERT ile ileriye ve geriye doğru hesaplanmış süreleri verilmiştir. Bununla beraber, ihracat sürecindeki ilgili faaliyetlerdeki boşluklar da belirtilmiştir. Boşluk değeri sıfır olan faaliyetler, kritik faaliyet olarak nitelendirilir. 
Tablo 5. Denisyolu ibracat faaliyetlerinin hesaplanmış PERT süreleri (dakika)

\begin{tabular}{|c|c|c|c|c|c|}
\hline Faaliyet & $\begin{array}{l}E S \\
\text { (Etken Basslama) }\end{array}$ & $\begin{array}{l}\text { EF } \\
\text { (Etken Bititme) }\end{array}$ & $\begin{array}{l}L S \\
\text { (GeçBaşlama) }\end{array}$ & $\begin{array}{l}L F \\
\text { (GeçBititme) }\end{array}$ & $\begin{array}{l}S \\
\text { (Bossluk) }\end{array}$ \\
\hline E1 & 0,0 & 1,5 & 0,0 & 1,5 & 0,0 \\
\hline E2 & 1,5 & 5,5 & 7,7 & 11,7 & 6,2 \\
\hline E3 & 1,5 & 10,4 & 1,5 & 10,4 & 0,0 \\
\hline E4 & 5,5 & 14,8 & 11,7 & 20,9 & 6,2 \\
\hline E5 & 10,4 & 20,9 & 10,4 & 20,9 & 0,0 \\
\hline E6 & 20,9 & 29,3 & 20,9 & 29,3 & 0,0 \\
\hline E7 & 29,3 & 35,6 & 29,3 & 35,6 & 0,0 \\
\hline E8 & 35,6 & 38,0 & 35,6 & 38,0 & 0,0 \\
\hline E9 & 38,0 & 41,4 & 38,0 & 41,4 & 0,0 \\
\hline E10 & 41,4 & 45,0 & 41,4 & 45,0 & 0,0 \\
\hline E11 & 45,0 & 49,7 & 45,0 & 49,7 & 0,0 \\
\hline E12 & 49,7 & 51,7 & 49,7 & 51,7 & 0,0 \\
\hline E13 & 51,7 & 55,8 & 51,7 & 55,8 & 0,0 \\
\hline E14 & 55,8 & 62,6 & 55,8 & 62,6 & 0,0 \\
\hline E15 & 62,6 & 65,2 & 62,6 & 65,2 & 0,0 \\
\hline E16 & 65,2 & 67,8 & 65,2 & 67,8 & 0,0 \\
\hline E17 & 67,8 & 70,3 & 67,8 & 70,3 & 0,0 \\
\hline E18 & 70,3 & 77,7 & 70,3 & 77,7 & 0,0 \\
\hline E19 & 77,7 & 84,3 & 82,2 & 88,8 & 4,5 \\
\hline E20 & 77,7 & 84,9 & 77,7 & 84,9 & 0,0 \\
\hline E21 & 65,2 & 67,8 & 86,2 & 88,8 & 21,0 \\
\hline E22 & 84,3 & 87,4 & 88,8 & 91,9 & 4,5 \\
\hline E23 & 41,4 & 44,9 & 86,1 & 89,6 & 44,7 \\
\hline E24 & 41,4 & 57,3 & 73,8 & 89,6 & 32,3 \\
\hline E25 & 84,9 & 91,0 & 89,6 & 95,7 & 4,7 \\
\hline E26 & 91,0 & 92,4 & 112,5 & 113,9 & 21,5 \\
\hline E27 & 84,9 & 91,3 & 84,9 & 91,3 & 0,0 \\
\hline E28 & 91,3 & 94,3 & 91,3 & 94,3 & 0,0 \\
\hline E29 & 84,3 & 88,1 & 90,6 & 94,3 & 6,3 \\
\hline E30 & 94,3 & 99,5 & 94,3 & 99,5 & 0,0 \\
\hline E31 & 99,5 & 102,7 & 102,9 & 106,1 & 3,4 \\
\hline E32 & 87,4 & 91,2 & 91,9 & 95,7 & 4,5 \\
\hline E33 & 91,2 & 94,4 & 96,3 & 99,5 & 5,1 \\
\hline E34 & 99,5 & 106,1 & 99,5 & 106,1 & 0,0 \\
\hline E35 & 91,2 & 93,2 & 113,8 & 115,8 & 22,7 \\
\hline E36 & 91,2 & 101,6 & 95,7 & 106,1 & 4,5 \\
\hline E37 & 92,4 & 94,3 & 113,9 & 115,8 & 21,5 \\
\hline E38 & 91,2 & 96,4 & 100,9 & 106,1 & 9,7 \\
\hline E39 & 94,4 & 99,8 & 110,4 & 115,8 & 16,0 \\
\hline $\mathrm{E} 40$ & 106,1 & 115,8 & 106,1 & 115,8 & 0,0 \\
\hline E41 & 94,4 & 100,9 & 104,3 & 110,8 & 9,8 \\
\hline E42 & 100,9 & 102,5 & 110,8 & 112,3 & 9,8 \\
\hline $\mathrm{E} 43$ & 102,5 & 106,0 & 112,3 & 115,8 & 9,8 \\
\hline E44 & 115,8 & 117,3 & 115,8 & 117,3 & 0,0 \\
\hline
\end{tabular}

Şekil 2'de denizyolu ihracat sürecin ağ diyagramı verilmiştir. Burada toplam 44 faaliyetten oluşan denizyolu ihracat sürecinin kritik yolu da, PERT simülasyon ve ayrıca klasik PERT ile belirlenmiştir. Kritik faaliyet ise; ihracat sürecinde tüm faaliyetlerin duraksama olmadan sürecin tamamlanmasını gerektiren faaliyetler olarak tanımlanabilir. Bu faaliyetlerde meydana gelebilecek bir gecikme, ihracat sürecinin aksamasına neden olacaktır. Bu faaliyetlerden 23 tanesi kritik faaliyet olarak hesaplanmıştır. Simülasyonla kritik yol, alternatif tamamlanma yollarının en uzun olanı olarak hesaplanmıştır. 


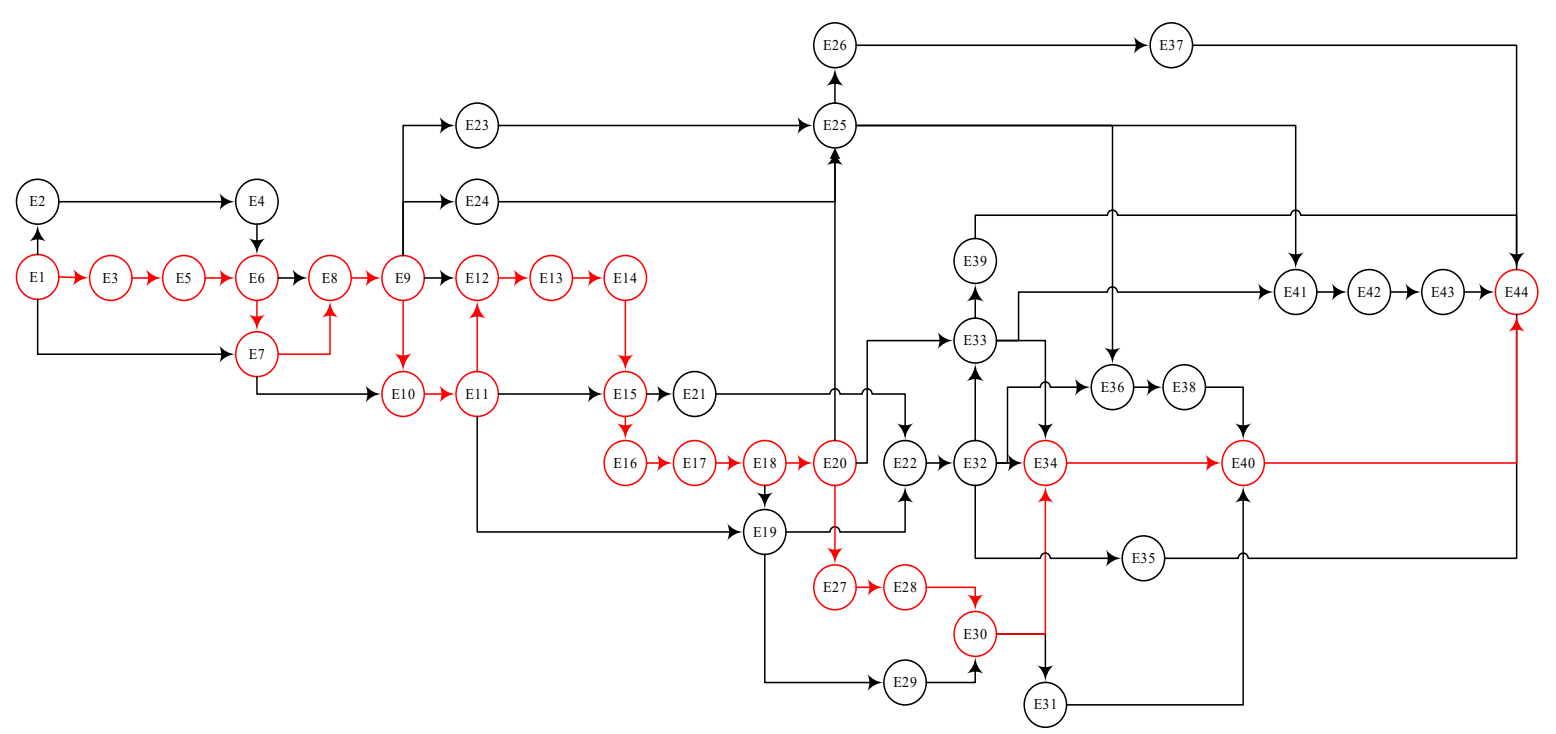

Şekil 2. Denisyolu ibracat süreci ağ diyagramı ve kritik, faaliyetler

Kritik Yol aşağıdaki faaliyetlerden oluşmaktadır:

\section{$\mathrm{E} 1 \rightarrow \mathrm{E} 3 \rightarrow \mathrm{E} 5 \rightarrow \mathrm{E} 6 \rightarrow \mathrm{E} 7 \rightarrow \mathrm{E} 8 \rightarrow \mathrm{E} 9 \rightarrow \mathrm{E} 10 \rightarrow \mathrm{E} 11 \rightarrow \mathrm{E} 12 \rightarrow \mathrm{E} 13 \rightarrow \mathrm{E} 14 \rightarrow \mathrm{E} 15 \rightarrow \mathrm{E} 16 \rightarrow \mathrm{E} 17 \rightarrow \mathrm{E} 18$ $\rightarrow \mathrm{E} 20 \rightarrow \mathrm{E} 27 \rightarrow \mathrm{E} 28 \rightarrow \mathrm{E} 30 \rightarrow \mathrm{E} 34 \rightarrow \mathrm{E} 40 \rightarrow \mathrm{E} 44$}

Tablo 6. Denisyolu İhracat sürecinin tamamlanması için PERT simülasyon istatistikleri

\begin{tabular}{ll}
\hline Simülasyon Sonuçlari & $\mathbf{t}$ (zaman) \\
\hline Simülasyon Döngüsü & 1.000 \\
Ortalama & 117,32 \\
Standart sapma & 4,59 \\
Minimum & 102,03 \\
Maksimum & 130,39 \\
Medyan & 117,23 \\
Çarpiklık & $-0,01$ \\
Basıklık & $-0,13$ \\
\hline
\end{tabular}

Bu kısımda PERT simülasyon değerleri incelenmiştir. Tablo 6'da denizyolu ihracat sürecinin kümülatif iş yükü simülasyonunun istatiksel değerleri bulunmaktadır. Buna göre simülasyon sonucunda bu değer ortalama 117,32 dakika, minimum 102,03 dakika ve maksimum 130,39 dakika bulunmuştur. Ayrıca, Şekil 3'de denizyolu ihracat sürecine ait kümülatif iş yükü simülasyonun histogram grafiği görülmektedir. Buna göre; simülasyon sonucunda bu değer, 106 ve 131 dakika arasında olup; yoğun olarak 117 ve 120 dakika civarında bulunmuştur. Burada en erken tamamlanma, kritik faaliyetin toplam zamanı olarak değerlendirilebilir. 117 dakikada tamamlanma olasıllğı, yaklaşık \%50 civarındadır.

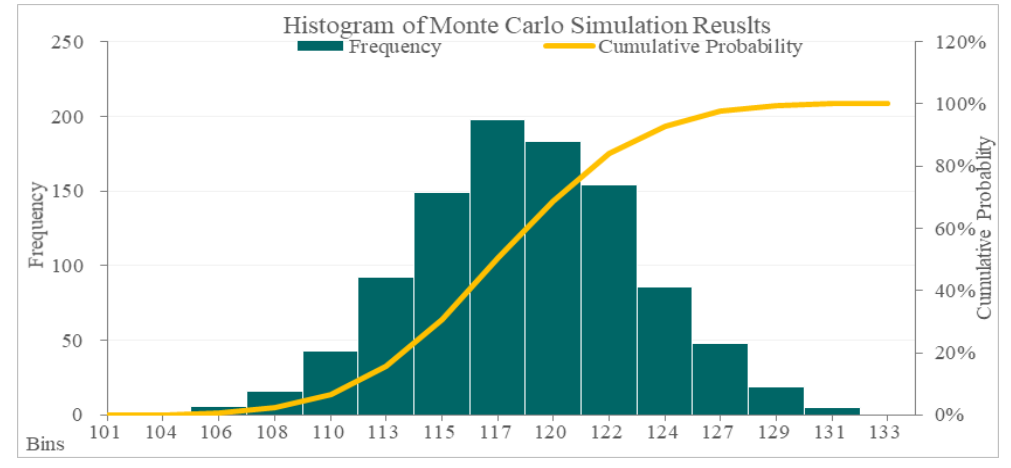

Şekil 3. PERT simülasyon histogram grafiği

Bununla birlikte simülasyonun kaç döngü olmasının belirlenmesi için ilk 10 deneme için Denklem (12)'de yerine koyarak; $\% 95$ güvenilirlik ve 0.59 (ortalama sürenin $\% 0,5$ 'i) hata payı ile en az tekrarlanmas1 gereken döngü sayısi; n=358 bulunur. En az 358 deneme yapmak gerekmektedir. Dolayısıyla simülasyon döngüsü 1000 olarak alınmıştır. 
Tablo 7'de denizyolu ihracat sürecine ait kümülatif iş yükü simülasyon sonuçlarının istatistikleri bulunmaktadır. Bu istatistikler, tüm sürece ayrllan zaman olarak değerlendirilebilir. Buna göre; simülasyon sonucunda bu değer, ortalama 220,08 dakika, minimum 193,91 dakika ve maksimum 274,25 dakika hesaplanmıştır. Ayrıca; Şekil 4'de denizyolu ihracat sürecine ait kümülatif iş yükü simülasyonunun histogram grafiği bulunmaktadır. Buna göre; simülasyon sonucunda bu değer, 195-264 dakika arasında olup; yoğun olarak 214 ve 220 dakika civarında bulunmuştur. Burada, tüm sürece ayrılan toplam iş yükü zamanı olarak değerlendirilebilir. 220 dakikada tamamlama olasıllŏı yaklaşık \%60 civarında olduğu görülmektedir.

Tablo 7. Denizyolu İbracat sürecinin toplam kümülatif PERT simülasyon istatistikleri

\begin{tabular}{ll}
\hline Simülasyon Sonuçlant & $\boldsymbol{t}$ (zaman) \\
\hline Simülasyon Döngüsü & 1.000 \\
Ortalama & 220,08 \\
Standart sapma & 12,57 \\
Minimum & 193,91 \\
Maksimum & 274,25 \\
Medyan & 218,14 \\
Çarpıklık & 0,70 \\
Basıklık & 0,48 \\
\hline
\end{tabular}

Bununla birlikte simülasyonun kaç döngü olmasının belirlenmesi için ilk 10 deneme için Denklem (12)'de yerine koyarak; $\% 95$ güvenilirlik ve 1,07 (ortalama sürenin $\% 0,5$ 'i) hata payı ile en az tekrarlanmas1 gereken döngü sayısı n=487 bulunur. En az 487 deneme yapmak gerekmektedir. Dolayisiyla simülasyon döngüsü 1000 olarak alınmıştır.

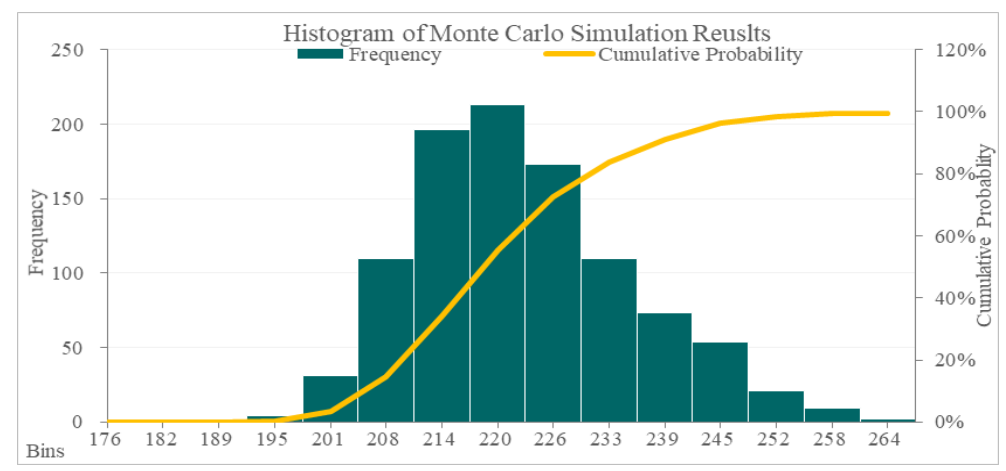

Şekil 4. Denizyolu İhracat sürecinin kümülatif PERT simülasyon histogram grafiüi

\section{Tartışma, Sonuç ve Öneriler}

Verimlilik temelli yaklaşımlar, her sektörde olduğu gibi, rekabetle beraber lojistik endüstrisini, dolayısıyla denizyolu lojistiğini de etkilemektedir. Bu çalışsmada; denizyolu lojistik ihracat operasyon sürecinin bütüncül analizi amacıyla, tüm süreç faaliyetlere (WBS) ayrıştırılarak, her bir faaliyetin süreleri PERT süreleri olarak atanmıstır. Bunun yanında denizyolu lojistik operasyonu sürecinin şebeke analizini yapabilmek, kritik yolu tayin edebilmek ve operasyon sürecinin tamamlanma süresiyle beraber toplam iş yükünü hesaplayabilmek için faaliyetler arasındaki ilişki yani öncül faaliyetler atanmıştır. PERT tekniği ve Monte Carlo simülasyon yöntemi uygulamada iki farklı simülasyon için uygulanmıştır. Birincisinde; denizyolu lojistik ihracat sürecinin tamamlanma süresine ve bu süreçteki kritik faaliyetlere odaklanılmıştır. Toplam 1.000 adet simülasyon döngüsü sonucunda, 4,59 dk. standart sapma ve yaklaşık 200 frekans ile simülasyonun ortalaması 117,32 dk. bulunmuştur. Bununla birlikte her bir faaliyet ayr1 ayrı incelendiğinde en çok zaman gerektiren faaliyetler; E5, E24 ve E36 faaliyetleri olduğu görülmektedir. Sürecin kritik yolu tayin edilmiştir, kritik yol 23 faaliyetten oluşmaktadır. Bu da, toplam faaliyetlerin \%52'ine karşıllk gelmektedir. İkincisinde ise; denizyolu lojistik ihracat sürecinin toplam iş süresine odaklanılmıstır. Toplam 1.000 adet simülasyon döngüsü sonucunda, $12,57 \mathrm{dk}$. standart sapma ve yaklaşık 210 frekans ile simülasyonun ortalamas1 220,08 dk. bulunmuştur.

Genel olarak denizyolu lojistik departmanlarındaki faaliyetler 1 operatör tarafindan gerçekleştirilmektedir. Analiz sonuçlarına bakıldığında; faaliyetlerin \%52'nin kritik faaliyet olması, 
operasyonunun tamamlanma süresini etkilemektedir. Çünkü faaliyetlerin tümü kritik faaliyet olduğu takdirde; operasyon sürecinin tamamlanma süresi ile toplam iş yükünün süresi aynı olacaktır. Bu çalışmada ise bu süre, yaklaşık iki katı olarak görülmektedir. Ancak operasyon sürecinde 1 kişiden daha fazla kişi iş bölümü yaparak sürecin yönetilmesini sağladığında, operasyon süreci daha verimli olacak ve yeri geldi mi operasyon sürecinin kısalmasına olanak sağlayacaktır. Bunun yanında operasyonda hızlı ve çevik olunması ya da gecikilmemesi isteniyorsa, öncelikle dikkat edilmesi gerekecek faaliyetler, kritik faaliyetler olacaktır. Ayrıca; simülasyon, bu konuda genel olarak operasyon sürecinin ne kadar sürede tamamlanacağ1 konusunda rehberlik etmektedir. Bunun yanında, en olası kritik yolun tayininde ve hesaplanmasında da yardımcı olmaktadır.

PERT tekniğinin simülasyon ile beraber kullanımı, literatürde Golenko-Ginzburg (1988) ve Davis. (2008) klasik PERT tekniğine olasillk temelli değişiklikler ile simülasyon entegre ederek, Lu ve AbouRizk (2000) risk yönetimi felsefesinde değerlendirerek, Bennett ve AbouRizk (2001) bu modelin hassasiyetini arttırarak proje süresinin tahmininde daha hassas sonuçlara varmıstır. PERT simülasyon, literatürde farklı alanlara uygulanmaktadır. (Haga ve O’keefe, 2001; Haga vd., 2004; Gray ve Reiman, 1976), ancak denizyolu lojistiğindeki uygulama için literatürde PERT simülasyon tekniği ile yapilan bir çalışmaya rastlanmamıştır. Bunun yanında; Akan ve Bayar (2020) denizyolu lojistiğinde fiyatlandırma süreç analizini bulanık simülasyon metodu ile ele almış, Rahardianto vd. (2018) limanda proses analizi için klasik PERT tekniğine başvurmuş, Tahar ve Hussain (2000) kaynak atamalarını, çizelgelemeleri ve performansı maksimize yapmak için uygulamışlardır. Bu çalışmayla beraber bu tekniğin denizyolu lojistiğinde proses analizinde de kullanılabileceği gösterilmiştir.

Dolayısıyla denizyolu lojistiğinin ihracat operasyon sürecinin gerek departman müdürleri, gerekse bizatihi operasyonu gerçekleştiren çalş̧anlar tarafindan daha iyi analiz edilerek; daha verimli bir şekilde yönetilmesini sağlayacaktır. Bunun yanında varyansı yüksek olan faaliyetlerin, yüksek belirsizlik içeren faaliyetler olduğu ve bu faaliyetlere gerekenden daha fazla önem verilmesi; hatta gerekli ise risk yönetimlerinin yapılması durumunda, operasyon sürecinin başarısına katkı sağlanacaktır.

Bu çalışmadaki literatüre olan katkı, denizyolu lojistiğinde ihracat sürecinin bütüncül olarak analiz edilmesi ve PERT tekniği ile Monte Carlo simülasyon yönteminin entegrasyonuyla yapılan detaylı analizdir. Model yaklaşımı bakış açısıyla değerlendirildiğinde, temelinde olasılık temelli bir sistem olduğu görülmekte; bu da, lojistik süreçlerinde belirsizliklerin olduğu durumlarda çözüme ulaşmada yardımcı olmaktadır.

Bu çalşşmanın temelinde bütüncül denizyolu ihracat süreci analiz edilmişken, bir başka çalışmada benzer yöntem ile denizyolu ithalat sürecinin analizi yapılabilir. Çalışmada önerilen metodoloji veya farklı metodolojiler ile beraber, lojistik süreçlerinin analizinin bir kısmında ya da farklı taşıma modları için de rahatlikla uygulanabilir.

\section{Etik Beyan}

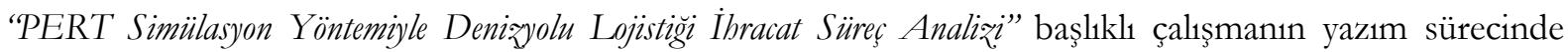
bilimsel kurallara, etik ve alıntı kurallarına uyulmuş; toplanan veriler üzerinde herhangi bir tahrifat yapılmamış ve bu çalşsma herhangi başka bir akademik yayın ortamına değerlendirme için gönderilmemiştir. $\mathrm{Bu}$ araştırmada hazır veri seti kullanıldığı için etik kurul kararı zorunluluğu taşımamaktadır.

\section{Kaynakça}

Aghaie, A. ve Mokhtari, H. (2009). Ant colony optimization algorithm for stochastic project crashing problem in PERT networks using MC simulation. The International Journal of Advanced Manufacturing Technology, 45, 1051-1067.

Badiru, A. B. (1991). A simulation approach to PERT network analysis. Simulation, 57(4), 245-255.

Bayar, S. ve Akan, E. (2020). Bulanık çevre ortamında monte carlo simülasyonu ile denizyolu lojistiği fiyatlandırma süreç analizi. Dumlupinar Üniversittesi Sosyal Bilimler Dergisi, (66), 22-40.

Bennett, F. L., Lu, M. ve AbouRizk, S. (2001). Simplified CPM/PERT simulation model. Journal of construction Engineering and Management, 127(6), 513-514.

Bowman, R. A. (1994). Stochastic gradient-based time-cost tradeoffs in PERT networks using simulation. Annals of Operations Research, 53(1), 533-551.

Branch, A. E. (2006). Export practice and management (5 ${ }^{\text {th }}$ Edition.) Cengage Learning EMEA., London: Thomson Learning.

Brandimarte, P. (2014). Handbook in Monte Carlo simulation: applications in financial engineering, risk management, and economics (1 ${ }^{\text {st }}$ Edition). New Jersey: John Wiley \& Sons. 
Bruzzone, A., Longo, F., Nicoletti, L., Bottani, E. ve Montanari, R. (2012). Simulation, analysis and optimization of container terminals processes. International Journal of Modelling, Simulation, and Scientific Computing, 3(04), 1240006, $1-20$.

Chávez, J. F., Novelli, A. C. ve Leon, M. P. (2020). Export Subsidies in Emerging Markets During the Great Trade Collapse. Economics Bulletin, 40(3), 1879-1892.

Chen, G. ve Yang, Z. (2010). Optimizing time windows for managing export container arrivals at Chinese container terminals. Maritime Economics \& Logistics, 12(1), 111-126.

Cottrell, W. D. (1999). Simplified program evaluation and review technique (PERT). Journal of construction Engineering and Management, 125(1), 16-22.

Çalışkan, A. ve Öztürkoglu, Y. (2018). Maritime logistics. İçinde S. Kamel, I. Lee, J. Kisielnicki, A. Gupta, C. van Slyke,J. Wang ve V. Weerakkody, (Edt.). In Intelligent Transportation and Planning: Breakthroughs in Research and Practice (ss. 822-845). IGI Global.

Davis, R. (2008). Teaching note-Teaching project simulation in Excel using PERT-beta distributions. INFORMS Transactions on Education, 8(3), 139-148.

Erera, A., Kwek, K. H., Goswami, N., White, C. ve Zhang, H. (2003). Comparison of Singapore and USA Sea Cargo Container Export Processes. Report, the Logistics Institute-Asia Pacific.

Gray, C. F. ve Reinman, R. E. (1976). PERT simulation: A dynamic approach to the PERT technique. İcinde I. B. Ibrahim K. K. Seo P. G. Vlachos, (Edt.). In Readings in Managerial Economics (ss. 82-93). New York: Pergamon.

Golenko-Ginzburg, D. (1988). On the distribution of activity time in PERT. Journal of the Operational Research Society, 39(8), 767-771.

Guarnaschelli, A., Bearzotti, L. ve Montt, C. (2017). An approach to export process management in a wood product enterprise. International Journal of Production Economics, 190, 88-95.

Haga, W. A. ve O'keefe, T. (2001). Crashing pert networks: A simulation approach. In 4th International conference of the Academy of Business and Administrative Sciences Conference. Quebec City, Canada, 12-14 July.

Haga, W. A. ve Marold, K. A. (2004). A simulation approach to the PERT/CPM time-cost trade-off problem. Project Management Journal, 35(2), 31-37.

Hämäläinen, E., Twrdy, E. ve Inkinen, T. (2017). Cost aggregation in export logistics chain. Journal of Open Innovation: Technology, Market, and Complexity, 3(26),1-14.

Hahn, G. J. (1972). Sample sizes for Monte Carlo simulation. IEEE Transactions on Systems, Man, and Cybernetics, 2(5), 678-680.

Jiang, B., Li, J. ve Gong, C. (2018). Maritime Shipping and Export Trade on "Maritime Silk Road". The Asian Journal of Shipping and Logistics, 34(2), 83-90.

Johnson, N. L., Kotz, S. I. ve Balakrishnan, N. (1994). Beta distributions. İçinde N. L. Johnson, S. Kotz ve N. Balakrishnan, (Edt) Continuous univariate distributions Volume 2. (2nd Edition). (ss. 221-235) New York, NY: John Wiley and Sons.

Jouili, T. A. (2019). Impact of seaport infrastructure, logistics performance, and shipping connectivity on merchandise exports. International Journal of Computer Science and Network Security, 19(5), 259-264.

Kang, J., Ryu, K. R. ve Kim, K. H. (2006). Deriving stacking strategies for export containers with uncertain weight information. Journal of Intelligent Manufacturing, 17(4), 399-410.

Karabulut, M. (2017). Application of Monte Carlo simulation and PERT/CPM techniques in planning of construction projects: A Case Study. Periodicals of Engineering and Natural Sciences, 5(3),408,420.

Kim, K. H., Park, Y. M. ve Ryu, K. R. (2000). Deriving decision rules to locate export containers in container yards. European Journal of Operational Research, 124(1), 89-101.

Lee, Y. ve Chao, S. L. (2009). A neighbourhood search heuristic for pre-marshalling export containers. European Journal of Operational Research, 196(2), 468-475.

Lee, E. S. ve Song, D. W. (2010). Knowledge management for maritime logistics value: discussing conceptual issues. Marit. Pol. Mgmt., 37(6), 563-583.

Lu, M. ve AbouRizk, S. M. (2000). Simplified CPM/PERT simulation model. Journal of Construction Engineering and Management, 126(3), 219-226.

Malcolm, D. G., Roseboom, J. H., Clark, C. E. ve Fazar, W. (1959). Application of a technique for research and development program evaluation. Operations research, 7(5), 646-669.

Manova, K. ve Zhang, Z. (2012). Export prices across firms and destinations. The Quarterly Journal of Economics, 127(1), 379-436.

Nam, H. S. ve Song, D. W. (2011). Defining maritime logistics hub and its implication for container port. Maritime Policy \& Management, 38(3), 269-292.

Pérez-Mesa, J. C., Galdeano-Gómez, E. ve Andújar, J. A. S. (2012). Logistics network and externalities for short sea transport: An analysis of horticultural exports from southeast Spain. Transport Policy, 24, 188-198.

Piltz, B. (2020). Incoterms 2020. Revija Kopaoničke škole prirodnog prava, 2(1), 9-28.

Pontrandolfo, P. (2000). Project duration in stochastic networks by the PERT-path technique. International Journal of Project Management, 18(3), 215-222. 
Rahardianto, R., Sarno, R. ve Budiawati, G. I. (2018). Performance Time Evaluation of Domestic Container Terminal Using Process Mining and PERT. International Seminar on Application for Tecbnology of Information and Communication. Semarang, Indonesia 21-22 Sep.

Tahar, R. M. ve Hussain, K. (2000). Simulation and analysis for the Kelang Container Terminal operations. Logistics information management, Vol.13, No.1, 14-20.

T.C. Ticaret Bakanlığı. (2020). Taşıma şekillerine göre dis s ticaret, https:/ / ticaret.gov.tr/data/5d63d89d13b8762f7c43a738/16-

Tasima\%20Sekillerine\%20Gore\%20Dis\%20Ticaret.pdf, Ziyaret Tarihi: 25.10.2020

Tenjo-García, J. S. ve Figueroa-García, J. C. (2019). Simulation-based fuzzy PERT problems. IEEE Colombian Conference on Applications in Computational Intelligence (ColCACI), Barranquilla, Colombia, 4-7 June.

Tongzon, J. L. (1989). The impact of wharfage costs on Victoria's export-oriented industries. Maritime Studies, 1989(46), 14-19.

Ueberhuber, C. W. (1997). Numerical Computation 2: Methods, Software, and Analysis. Berlin: Springer Science Business Media.

Uddin, K. S. ve Jinia, A. A. (2017). Simulation of Automated Warehouse System: Using CPM and PERT Method. Simulation, 9(11),123-134.

UNCTAD. (2020). Review of Maritime Transport 2019, United Nations Conference on Trade and Development, New York: United Nations Publications.

Utikad. (2020). Incoterms 2020, https://www.utikad.org.tr/Images/Duyuru/08012020incoterms2020414196.pdf , Ziyaret Tarihi: 17.10 .2020$.

Vose, D. (2008). Risk analysis: a quantitative guide (3rd Ed). West Sussex: John Wiley \& Sons.

\section{EXTENDED ABSTRACT}

In the light of technological developments, both the introduction of mass production and globalization, the logistics processes in the entire supply chain from the final product to the customer delivery involve a complex structure. As it is known, one of the most important links of the supply chain is the transportation ring. For this reason, it is of great importance to manage the logistics process of this ring effectively and efficiently, as well as other links in the chain supply. A good management of this process results in running the process smoothly. However, a remarkable part of the cargoes carried for international trade in the world are transported by seaway.

From this perspective, maritime export transportation process, which plays an important role in the economy of countries, has been discussed. If we look at the main lines in international maritime transport, the exporter company contracts with a logistics firm or freight forwarder to transport its goods and sends the goods to the importer company. Before the sender and the recipient begin the transportation, INCOTERMS sign an agreement in accordance with the one of the delivery methods and the responsibilities of the sender and the receiver in the transportation are determined with this contract. The study was examined according to the FOB (Free On Board) delivery method, which is one of these INCOTERMS delivery types, and was discussed in terms of the sender's responsibility. In this context, according to the FOB delivery method, the main shipping responsibility belongs to the buyer. However, the responsibility of all processes up to the board of the ship belongs to the sender. Therefore, this study analysed the process up to the board of the ship, taking into account the responsibility of the exporter within the scope of FOB delivery method.

Marine logistics is an effective planning, management and implementation of all processes in maritime operations; all processes will be put forward and calculating the duration of these processes, critical activities and abundances will ensure effective time management and prevent possible problems and congestions. In this context, all activities belonging to the maritime export process of a logistics enterprise operating in maritime logistics and the PERT periods of these activities have been determined. In addition, the relationship between activities of the export process in maritime logistics, particularly, the primary activities of the activities have been determined. As a result, it is aimed to analyse the completion time of the maritime logistics export process, the total workload time and the critical route using the PERT Simulation method.

Unlike deterministic approaches, Probability-based approaches give successful results in decisionmaking problems in case of uncertainty. Therefore, the preference for the probability-based approach for this study is that the processes contain uncertainty and change depending on the characteristics of each load. In addition, problem solving with a wider perspective is aimed with PERT and Monte Carlo simulation method. 
In this study, for the purpose of a holistic analysis of the maritime logistics export operation process, the duration of each activity has been assigned as PERT periods by separating the entire process into activities (WBS). In addition, preliminary activities have been assigned to analyse the network of the maritime logistics operation process, to determine the critical path and to calculate the total workload with the completion time of the operation process. PERT technique and Monte Carlo simulation method were applied for two different simulations in practice. In the first simulation, the focus is on the completion time of the maritime logistics export process and the critical activities in this process. As a result of a total of 1000 simulation cycles, the average simulation value was found to be 117.32 minutes with a standard deviation of 4.59 minutes and a frequency of approximately 200 .

However, when each activity is examined separately, the most time-consuming E5, E24 and E36 activities are observed. The critical path of the process has been determined; the critical path consists of 23 activities. This corresponds to $52 \%$ of the total activities.

Then the total business time of the seaway logistics export process is focused. As a result of a total of 1,000 simulation cycles, 12.57 minutes. The average of the simulation with a standard deviation and a frequency of 210 is $220,08 \mathrm{~min}$. has been found.

In the second simulation, focus is made on the total process of marine logistics exports. As a result of a total of 1000 simulation cycles, the average simulation value was found to be 220.08 minutes with a standard deviation of 12.57 minutes and a frequency of approximately 210.

The contribution to the literature in this study is the holistic analysis of the export process in maritime logistics and the detailed analysis made by integrating the PERT technique and Monte Carlo simulation method. When evaluated from the point of view of the model approach, it is seen that there is a probability-based system on its basis, which helps to reach a solution in cases where there are uncertainties in logistics processes. 